\title{
A Review on the Contemporary Changes of Capital Structures for the Firms belonging to the Korean Chaebols
}

\author{
Hanjoon $\mathrm{Kim}^{1^{*}}$ \\ ${ }^{1}$ Dept. of Business Administration, Hoseo University \\ 한국 재벌기업들의 자본구조변화 추이에 관한 \\ 재무적 관점에서의 고찰 \\ 김한준 ${ }^{*}$ \\ ${ }^{1}$ 호서대학교 사회과학대학 경영학과
}

\begin{abstract}
This study examined a long-standing issue with its perverse results in the Korean capital markets, such as any variant financial profiles over time, affecting capital structure for the firms belonging to the chaebols. It may be of interest to identify these components from the perspectives of international investors and domestic policy makers to implement their contingent strategies on the target leverage, since the U.S. financial turmoils in the late 2000s. Regarding the evidence from the three hypothesis tests on the firms in the chaebols, this research found that the control variabels measuring profitability, business risk, and non-debt tax shields, showed their statistically significant relationships with the different types of a debt ratio. While FCFF(free cash flow to the firm) showed its significant influence to discriminate between the firms in the chaebols and their counterparts, not belonging to the chaebols, BDRELY as the ratio of liabilities to total assets, comprising the enhanced 'Dupont' system, only showed its statistically significant effect on leverage in the context of the parametric and nonparametric tests. In line with the results obtained from the present research, one may expect that a firm in the Korean chaebol, may control or restructure its present level of capital structure to revert to its target optimal capital structure towards maximizing the shareholders' wealth.
\end{abstract}

요 약 본 연구의 주제는 국내자본시장관련 재무적인 측면에서 장기적인 이슈가 되고 있는 대규모기업집단(소위 '재 벌')소속 계열사들의 자본구조 결정에 대한 재무적 특성요인들의 시대적 변화양태를 분석하는 것이며, 이와 관련하여, 1997년의 아시아 금융위기와 2009년 미국발 국제금융위기 등의 주요 금융 사건들의 발생에도 불구하고, 지속적이고 강건성있는 유의적 재무적 특성을 파악하는 것이 연구의 주된 목적이라고 판단한다. 이를 통하여, 국내 기업 뿐만 아 니라, 향후 국내자본시장의 선진시장으로의 분류상 진입가능성과 부합하여, 점진적으로 증가될 것으로 예상되는 외국 자본의 국내 직접투자 시 적정자본구조 설정에 대한 참고적 기여도도 추가적인 목적이 될 수 있다. 본 문에서는 재벌 계열사들의 부채비율관련, 3 가지의 가설들이 설정, 검정되었으며, 다음의 주요 결과들이 도출되었다. 첫째, 시계열자료 사용관련, 패널자료분석 결과 장부가와 시장가기준 부채비율에 영향을 주는 통계상 유의적 결정요인들로서는 수익성, 순이익의 변화도(즉, 위험도), 그리고 비부채적 법인세 감면효과 등으로 판명되었다. 두 번째 가설관련, 프로빗 모형을 이용한 재벌계열사와 비재벌계열사들의 자본구조에 영향을 줄 수 있는 차별적 구성요인들 검정관련, 수익성과 잉여현 금흐름에 대한 변수들이 통계적 유의성을 보였고, 마지막 가설에서는 제조업의 수익성분석에서 전통적으로 활용되었 던 ‘듀퐁시스템’을 부채비율 관점에서 응용하여, 이에 대한 구성요인들을 모수 그리고 비모수의 통계적 분석을 활용 하여 분석한 결과, 차입금의존도(부채/자산총계) 만이 유일한 유의성을 나타낸 것으로 분석되었다.

Key Words : Financial Profile, Chaebol, Korean Capital Market, Panel Data Model, Probit Model, Dupont System

"Corresponding Author : Hanjoon Kim(Hoseo Univ.)

Tel: +82-41-560-8369 email: khj723@hoseo.edu

Received September 10, 2013 Revised October 28, $2013 \quad$ Accepted January 9, 2014 


\section{Introduction}

This study addresses one of the contemporary issues concerning the capital structures for the firms belonging to the Korean conglomerates, 'chaebols', in its capital market. such as any transitional possible changes and components of the capital structure. It may be of interest and even importance to identify these possible new trends from the perspectives of international investors and domestic policy makers to implement their contingent strategies, given the dynamic changes on the restructuring of leverage for the firms classified into the chaebols since the Asian financial crisis in the late 1990s and the U.S. financial turmoils in the late 2000s. Moreover, from academics' and practitioners' points of vies, it may be of concern to look into or reexamine the level of capital structure for a firm belonging to the chaebol headquartered in Korea, whose level may have artificially been lowered than its previous level in the Asian financial crisis, largely due to the active implementation of the domestic policies of the government in cooperation with IMF, as presented in [1]. In accordance with the results obtained from the present research, one may expect that a firm in the Korean chaebol may control or restructure its present level of capital structure to revert to its target optimal capital structure, which may, in turn, maximize its firm value as modeled in Modigliani \& Miller[2].

Major contributions attributed by this particular study may be exposited as follows: First, the hypothesis on the level of leverage for the firms grouped in each chaebol was one of the prolonged and controversial issues pervasive in the Korean capital markets. That is, the chaebol was regarded as a by-product of the rapidly growing Korean economy since the 1960 s and possessed some similarities with the institutions of the Japanese keiretsu in their structures, but were not identical in the characteristics.[3] They seemed to have implicit priority in raising debt capital from the domestic government with lower cost of debt than those firms, not in the chaebols.[3,4] The studies done by Kim \& Berger[3] and Kim[5] found that the firms in the former groups were highly levered than their counterparts by utilizing each different sample period such as the years from 1987 to 1991 and just after the Asian financial crisis (from 1999 to 2003), respectively. Therefore, one of the contributions in this study may look into the contemporary results as to whether the debt ratios of the firms in the chaebols, have been, on average, restructured or stayed constant in comparison with those of their counterparts through the longstanding implementation of massive debt policies at the government level. Second, as for a robustness check, any unique financial elements discriminating between the firms in the chaebols and their counterparts relative to capital structure, may be compared with the results obtained in the previous study such as in [6] and thereby, any consistent outcomes over time, are expected to be the robust financial attributes of the chaebol firms concerning leverage. In other words, assuming the robust and consistent results, any new or untraversed interpretations may be applicable to those firms in examining possible financial characteristics possessed by the Korean chaebols, applicable over time. Finally, in many aspects, the chaebol seemed to be ambivalently evaluated in terms of their contribution on the national economy. Accordingly, it may be unreasonable or even impossible in reality, to undervalue their importance on the national wealth of Korea, considering their aggregate sizes, earnings, and market capitalization. Therefore, given a type of organization as export-oriented multinational corporation belonging to the chaebol, it may also be worth identifying any statistically significant determinants affecting the capital structures of the firms in the group, especially when overseas institutions plan to domestically invest in a large size firm with its longer corporate history in the domestic capital market.

This study consists of as follows: Following the first section as introduction, a main body of this study such as the sections describing a review on previous literature, data collection and methodologies for postulated hypotheses, and analyses and interpretations, were presented in sequence. Especially, the frequently cited and/or referred, previous researches on capital structure, as included in [5] and [6] were described and the data collection criteria with the definitions of independent and dependent variables employed, were illustrated in each corresponding section. Finally, concluding remarks for potential readers, were presented with a summary of the results of the present study. 


\section{Review on the Previous Literature}

As described, the previous literature on capital structure including those for the firms belonging to the chaebols in the Korean capital markets, were chronologically reviewed in this section, most of which had been frequently referred and/or cited in the previous researches such as in [5] and [6].

Krishnan \& Moyer[7] performed an international study to find the determinants of corporate performance and capital structure for four countries such as Hong Kong, Korea, Malaysia, and Singapore. Their results supported that Korean firms, on average, had a statistically significant market value based leverage ratio which was higher than those of the firms from the other three countries. They argued that the close linkages between chaebols and domestic banks in Korea may well result in the higher leverage of Korean firms in the sample. Moreover, size and tax effects were the significant determinants of capital structure after controlling for country and industry influence. Deesomsak et al.[8] investigated the determinants of corporate capital structure in the Asia Pacific region, including Malaysia, Thailand, Singapore, and Australia, covering the period of 1993-2001. They found that the firm size effect on leverage was statistically significant and positive for most countries in the region after the 1997 financial crisis, and argued that this was due to higher concerns about possible bankruptcy or default risk. Across all sample countries for the entire period studied, non-debt tax shield, liquidity, and share price performance among several explanatory variables tested, had a statistically significant effect on leverage. By employing a large panel for the years 1992-2001, a time that included the pre- and post- financial crisis in South Korea, Fattouh et al.[9] found that there were systematic relationships between the capital structure and the proxy variables for asymmetric information cost. The firm size effect on the capital structure was insignificant or significantly negative at the higher levels of leverage, as the companies were notable to borrow at favorable terms in the capital markets, since their leverage became too high. Non-debt tax shield asset tangibility was significantly related to leverage as expected. Profitability was statistically significant and negative across nearly all quantiles, as the pecking order hypothesis suggested. By using time dummies, they suggested that industrial and financial restructuring policies adopted after the 1997 financial crisis in South Korea led to a wide spread shift in the relationship between firms' financing and the costs resulting from asymmetric information.

Park et al.[10] performed two sets of tests to analyze the differences between the chaebol firms and the non-chaebol ones and between more levered and less levered chaebols. Regarding the first result, the significant relationship was found between the investment and their growth opportunity for the chaebols, while the reverse was true for the non-chaebols. Second, they presented that more statistically significant relationships were found between the investments and the growth opportunities, as the chaebol firms decrease their levels of leverage. As one of the recent studies. Choi[11] also investigated any financial differences between the rising (or survived) and the failing chaebols during the 1997 financial crisis. The paper found that there were no statistically significant differences in terms of inside ownership between the two chaebol-related groups, after controlling for the size effect. The failing group was also found that they were more diversified than their counterparts mainly due to the lower cost of borrowing, which thereby resulted in the decreasing net income.

The study by Kim \& Berger[3] investigates two prolonged controversial issues concerning Korean chaebols vs. non-chaebols. The Korean chaebol can be thought of, in a macro sense, as similar to the Japanese Keiretsu, although there are several differences which are noted in the paper. One of the issues investigated is whether firms belonging to the Chaebol in Korea have different market-value based debt ratios than their counterparts not belonging to the chaebol. If this is so, there are several managerial implications. Results indicate that, for the period studied, firms in the chaebol did have a higher mean leverage than their counterparts. The other issue addressed used logistic regression analysis to determine that firms belonging to the chaebol appeared to possess different levels of the following characteristics in comparison with firms not belonging to the chaebol: larger size measured by total sales, higher sales growth rate, lower profitability, and lower business risk (although the latter difference was not statistically 
significant, only directional).

Kim[5] tested several major analyses to find any differences in the leverage between the pre- and post-period of the currency crisis. It was found that firms belonging to the chaebol in Korea maintained higher average book-value and market-value based debt ratios, relative to their counterparts not belonging to the chaebol across all of the tested models. There were positive relationships of IND3(=the chemical industry) and Ind5(=the construction industry) to the book-value leverage. This study identified that there were no differences in the explanatory variables included, between the tested models (that is, without and with including the present value of an operating lease) related to each debt ratio. Since the Korean government continue to improve the corporate governance of the domestic firms in terms of accounting transparency and corporate ownership, it would be more efficient, if utilizing this "new" ratio considering an operating lease as an effective measurement of the level of leverage.

\section{Data Collection and Methodology}

\subsection{Data Collection Criteria}

The sample firms belonging to the chaebols and not to the chaebols, were finalized in this study, according to the following criteria.

[Table 1] Data for the Korean Sample Firms

1. All the data for each sample firm were available for at least six years from 2006 to 2011, including the recent financial turmoil occurred in 2008-2009.

2. The sample firms were listed on the KOSPI market at the end of December 2011. They were also included in the databases of New KisValue (published by the NICE in Korea).

3. The largest 13 corporations ranked by asset size, were selected for each corresponding industry whose classifications or definitions were matched with those adopted in $\operatorname{Kim}[5]$.

4. The criteria to classify a firm as belonging to the chaebol, followed the guideline by the Fair Trade Commission in the Republic of Korea, such that it was belonging to a large business group, subject to the limitation on cross-shareholding.

5. Financial and regulated industries were not included in the final sample.

\subsubsection{Dependent Variable(DV)}

In this study, a broader spectrum of DVs was employed to test for each corresponding hypothesis postulated in this study. First, a book-value based debt ratio defined by total liabilities divided by total assets, was used as a measure for the DV, considering the advantage of this particular ratio (over other major debt ratios), in that it was the only financial ratio with a normal distribution, as tested in [12] and [13]. Second, a market value-based leverage ratio was adopted in the tested model to be a more representative $\mathrm{DV}$ in the context of finance theory. It was defined by the ratio of total liabilities to the sum of total liabilities, preferred stock, and market-value of equity. Lastly, as one of the alternative DVs, the measure referred to as 'Degree of Financial Leverage(DOF), was utilized and tested in the model, which may imply an indirect relationship between EBIT(earnings before interest and taxes) and EPS (earnings per share). That is, the value of the DOF is greater than or equal to 1 , as defined by EBIT/(EBIT -interest charges), and it indicates that the value of DOF may simultaneously increase, if interest expenses as a fixed cost on corporate borrowings become larger[14].

(1) Book-value based debt ratio:

1) BVLEV1 = Total liabilities/Total Assets

2) BVLEV2 = Degree of Financial Leverage (DFL)

$$
=\mathrm{EBIT} /(\mathrm{EBIT}-\text { Interest charges) }
$$

(Note: EBIT is defined as earnings before interest and taxes)

(2) Market-value based debt ratio:

1) MVLEV1 = Total liabilities/(Total liabilities + Market Value of Equity + Preferred Stock)

\subsubsection{Independent Variable(IDV)}

In association with their theoretical and practical importance as in the previous (finance) literature in variable selection process, this study also reemployed and tested the majority of the independent variables(IDVs), which had been tested in the comparable researches such as in [1] and [6] to test for each relevant hypothesis towards their consistency and robustness as described earlier. The followings were the variable definitions to be utilized for the explanatory variables. 
[Table 2] Independent Variable Definitions

\begin{tabular}{|c|c|c|}
\hline Definition & $\begin{array}{c}\text { Proxy } \\
\text { Variable }\end{array}$ & Measurement \\
\hline \multirow[t]{2}{*}{ Profitability } & PFTD & $\begin{array}{c}\text { Earnings before } \\
\text { interest, taxes, and } \\
\text { depreciation \& } \\
\text { amortization(EBITDA) / } \\
\text { Book value of assets at } \\
\text { the fiscal year-end }\end{array}$ \\
\hline & PM & Net income / sales \\
\hline $\begin{array}{l}\text { Market value } \\
\text { of equity }\end{array}$ & MVE & Market value of equity \\
\hline Size & SIZE & $\begin{array}{c}\text { Sales amount at fiscal } \\
\text { year-end }\end{array}$ \\
\hline Business risk & RISK & $\begin{array}{l}\text { Standard deviation of } \\
\text { net income during the } \\
\text { sample period }\end{array}$ \\
\hline $\begin{array}{l}\text { Market- to } \\
\text { book- value } \\
\text { of equity }\end{array}$ & MVBV & $\begin{array}{c}\text { Market value of } \\
\text { equity / book value of } \\
\text { equity }\end{array}$ \\
\hline Growth & GROWTH & $\begin{array}{c}\text { Annual average } \\
\text { compound growth rate } \\
\text { in sales during the } \\
\text { sample period }\end{array}$ \\
\hline $\begin{array}{l}\text { Non-debt tax } \\
\text { shield }\end{array}$ & NDTS & $\begin{array}{c}\text { Annual Depreciation \& } \\
\text { Amortization scaled by } \\
\text { total assets at fiscal } \\
\text { year-end }\end{array}$ \\
\hline $\begin{array}{c}\text { Foreign } \\
\text { ownership }\end{array}$ & FOS & $\begin{array}{l}\text { Foreign ownership of } \\
\text { each KOSPI listed } \\
\text { sample firm }\end{array}$ \\
\hline $\begin{array}{l}\text { Free cash } \\
\text { flow }\end{array}$ & FCFF & $\begin{array}{l}\text { Earnings after corporate } \\
\text { taxes - (net changes of } \\
\text { the amount of assets } \\
\text { during a fiscal year) }\end{array}$ \\
\hline Industry & Ind & $\begin{array}{l}\text { IND1 = } 1 \text { if industry = } \\
\text { food. } 0 \text {, otherwise; } \\
\text { IND2 = } 1 \text { if industry = } \\
\text { pharmaceutical1. 0, } \\
\text { otherwise; } \\
\text { IND3 = } 1 \text { if industry = } \\
\text { chemical. } 0 \text {, otherwise; } \\
\text { IND4 = } 1 \text { if industry } \\
\text { =semiconductor \& } \\
\text { communication. } 0, \\
\text { otherwise; } \\
\text { IND5 = } 1 \text { if industry = } \\
\text { construction. } 0, \\
\text { otherwise; } \\
\text { (Base industry = the } \\
\text { wholesale industry) }\end{array}$ \\
\hline Fiscal year & fyear & $\begin{array}{l}\mathrm{f} 2007=1 \text { if a fiscal } \\
\text { year is ' } 2007 \text { '. O, } \\
\text { otherwise; } \\
\mathrm{f} 2008=1 \text { if a fiscal } \\
\text { year is '2008'. O, }\end{array}$ \\
\hline
\end{tabular}

\begin{tabular}{|c|c|c|}
\hline & & $\begin{array}{l}\text { otherwise; } \\
\mathrm{f} 2009=1 \text { if a fiscal } \\
\text { year is '2009'. O, } \\
\text { otherwise; } \\
\mathrm{f} 2010 \text { = } 1 \text { if a fiscal } \\
\text { year is ' } 2010 \text { '. O, } \\
\text { otherwise; } \\
\mathrm{f} 2011 \text { = } 1 \text { if a fiscal } \\
\text { year is ' } 2011 \text { '. O, } \\
\text { otherwise; } \\
\text { (Base fiscal year = the } \\
\text { year 2006) }\end{array}$ \\
\hline Chaebol & CBOL & $\begin{array}{c}\text { CBOL }=1 \text { if a firm } \\
\text { belongs to the chaebol, } \\
\text { 0, otherwise. }\end{array}$ \\
\hline
\end{tabular}

\subsection{Methodologies Applied to Each Hypothesis}

This section articulated the tests for three major hypotheses postulated on the financial components of the capital structure for the firms belonging to the chaebols, applying each corresponding methodology. Thereby, any statistically significant results were expected be derived for the present research. The following part consists of the three hypotheses postulated:

\section{$<$ Hypothesis 1>}

$H_{0}:$ A firm belonging to the chaebol in the Repulic of Korea, has no statistically significant financial characteristics to affect its capital structure by applying the panel data model duriing the sample period.(i.e., the years from 2006 to 2011)

The Korean government (The Fair Trade Commission(FTC)) announces the so-called as 'Large Business Groups(LBGs)' as of the beginning of April, each year, on a regular basis. As described in Table 1, the criteria to classify a firm into a chaebol, followed the guideline for a firm belonging to the above 'Large Business Group' subject to the limitation on cross-shareholding, as defined by the FTC. Moreover, the methodology of a panel data analysis was formulated as follows[15]:

$$
\begin{aligned}
\mathbf{Y}_{\mathbf{i t}}= & \mathbf{b}_{\mathbf{0}}+\mathbf{b}_{\mathbf{1}} \mathbf{X}_{1 \mathbf{i t}}+\mathbf{b}_{2} \mathbf{X}_{2 \mathbf{i t}}+\ldots \ldots+\mathbf{b}_{\mathbf{k}} \mathbf{X}_{\mathbf{k i t}} \\
& +\mathbf{a}_{\mathbf{i}}+\mathbf{u}_{\mathbf{i t}} \\
& , \text { where ai is the unobserved effect. } \\
& \mathrm{u}_{\mathrm{it}} \text { is the error term assumed to be }
\end{aligned}
$$


independent and identically distributed.

$\mathrm{i}=1,2, \ldots . ., \mathrm{n}$ (for each firm), and

$\mathrm{t}=2005,2006, \ldots \ldots, 2010$.

$\mathrm{k}=$ total number of exogenous variables, and

$\mathrm{j}=1,2, \ldots ., \mathrm{k}$.

If $\operatorname{Cov}\left(\mathrm{X}_{\mathrm{jit}}, \mathrm{a}_{\mathrm{i}}\right)=0, \mathrm{a}$ random effects model.

Otherwise, a fixed effects model.

Moreover, it may be of concern that a firm belonging to the chaebol may possess any statistical differences in the financial characteristics (affecting the level of leverage) from the non-chaebol. Consequently, the results obtained from this hypothesis test may be compared with those of the previous studies such as in those of Kim \& Berger[3] for the consistency and robustness across time periods, and the relevant hypothesis can be posited as follows:

\section{$<$ Hypothesis 2>}

$H_{0}:$ A firm classified into the chaebol in the Korean capital markets, may not have different mean-value based financial elements from those of the non-chaebol in during the recent selected period.

In particular, the probit analysis was used to model this hypothesis as to whether there may be any discriminating components between the two compared groups.

The basic functional form of the probit model is as follows[16]:

$$
\begin{aligned}
& Y_{t}=1, \text { if } \alpha+\beta \mathbf{X}_{t}+U_{t}>\mathbf{0} \\
& Y_{t}=\mathbf{0}, \text { if } \alpha+\beta \mathbf{X}_{t}+U_{t} \leq \mathbf{0}
\end{aligned}
$$

If $F(z)$ denote the cumulative distribution function of the normal distribution such that $\mathrm{F}(\mathrm{z})=\mathrm{P}(\mathrm{Z} \leq \mathrm{z})$, then

$$
\begin{aligned}
\mathbf{P}\left(\mathbf{Y}_{\mathbf{t}}\right. & =\mathbf{1})=\mathbf{P}\left(\mathbf{U}_{\mathbf{t}}>{ }_{-}-\boldsymbol{\alpha}-\beta \mathbf{X}_{\mathbf{t}}\right) \\
& =\mathbf{1}-\mathbf{F}((-\alpha-\beta \mathbf{X}) / \sigma) \\
\mathbf{P}\left(\mathbf{Y}_{\mathbf{t}}\right. & =\mathbf{0})=\mathbf{P}\left(\mathbf{U}_{\mathbf{t}} \leq{ }_{-} a-\beta \mathbf{X}_{\mathbf{t}}\right) \\
& =\mathbf{F}((-a-\beta \mathbf{X}) / \sigma)
\end{aligned}
$$

, where $\mathrm{P}\left(\mathrm{Y}_{\mathrm{t}}=1\right)$ is the probability that a firm is classified into the one belonging to the chaebol, which is bounded between 0 and 1 .

It labels $\alpha$ and $\beta$ as the intercept and vector of slope parameters, respectively. $\mathrm{x}$ is a vector of independent variables at each studied year.
Subsequently, the probit analysis is modeling the aforementioned probability by assigning the dummy variable, $\mathrm{CBOL}=1$ (if a firm belongs to the chaebol) and $\mathrm{CBOL}=0$, otherwise.

Finally, an extended (or enhanced) version of the 'Dupont' system applied to a 'financial burden' was employed for the third hypothesis test to identify each possible disparity among the four relevant factors comprising the version or equation. A 'financial version' modified by the 'Dupont' system was frequently referred in the finance text and also tested as in [17]. In this particular study, an extended version of this modified system can be formulated by utilizing the concept of the times-interest-earned(TIE) relative to leverage, which has been practically paid attention to most firms in the Korean capital market since the Asian financial turmoil in 1997[18]. The equation of the enhanced version was formulaed as follows:

\section{Interest charges / EBIT}

$=1 /$ (Times-interest-eamed)

$=$ Financial Burden $\mathbf{x}$ (Sales/EBIT)

$=$ Borrowing Cost $x$ Debt Burden $x$ 1/Asset Tumover $x$ (1/Operating Profit to Sales)

$=\{$ (Interest charges/Liabilities $) \times$ (Liabilities/Assets $) \mathbf{x}$ (Assets/Sales)\} x (Sales/EBIT)

\section{$<$ Hypothesis 3>}

$H_{0}:$ A firm belonging to the Korean chaebol, may not have any statistically significant disparity in its components (i.e., Debt Burden, Borrowing Cost, 1/Asset Turnover, and 1/Operating Profit to Sales) composing the enhanced version of the modified 'Dupont' system (i.e., Financial Burden), in comparison with the non-chaebol.

Accordingly, the four components in the aforementioned equation with respect to the level of leverage, was separately tested between the firms in the chaebols and in the non-chaebols, respectively. That is, for the test of each component, both the independent samples t-test (as a parametric test) and the Wilcoxon-Mann-Whitney test (as a non parametric one) were employed for mutual complement. 


\section{Analysis and Interpretation}

\subsection{Analyses}

The descriptive statistics including Pearson's correlation covariance matrix between the IDVs. for the sample firms belonging to the chaebols were presented in the following tables. Moreover, any interpreations or implications on the results from each corresponding hypothesis test were separately illustrated in the following section, [4.2 Interpreations].

[Table 3] Descriptive Statistics for IDVs

\begin{tabular}{|c|c|c|c|c|c|c|}
\hline IDV & N & Mean & Median & STD & Maximum & $\begin{array}{c}\text { Mini } \\
\text { mum }\end{array}$ \\
\hline P & 199 & 0.07 & 0.06 & 0.05 & 0.22 & -0.11 \\
\hline SZ & 199 & 1.32 & 5.97 & 2.54 & $1.65 \mathrm{E} 14$ & $4.17 \mathrm{E} 11$ \\
\hline G & 199 & 0.12 & 0.12 & 0.08 & 0.34 & -0.04 \\
\hline M & 199 & 1.38 & 1.20 & 0.98 & 7.16 & 0.16 \\
\hline R & 199 & $3.05 \mathrm{E} 11$ & $8.59 \mathrm{E} 10$ & $7.53 \mathrm{E} 11$ & $3.84 \mathrm{E} 12$ & $1.01 \mathrm{E} 9$ \\
\hline ND & 199 & 0.004 & 0.002 & 0.004 & 0.02 & 0 \\
\hline
\end{tabular}

(Note): $\mathrm{N}=$ Number of firms in the chaebols, $\mathrm{STD}=$ Standard deviation $\mathrm{P}=\mathrm{PFTD}, \quad \mathrm{SZ}=\mathrm{SIZE}, \mathrm{G}=\mathrm{GROWTH}, \mathrm{M}=\mathrm{MVBV}$, $\mathrm{R}=\mathrm{RISK}, \mathrm{ND}=\mathrm{NDTS}$

[Table 4] Pearson's Correlation Coefficient Matrix between IDVs

\begin{tabular}{|c|c|c|c|c|c|c|}
\hline IDV & P & SZ & G & M & R & ND \\
\hline P & 1.00 & 0.11 & $0.18^{*}$ & $0.34^{*}$ & $0.20^{*}$ & $0.20^{*}$ \\
\hline SZ & & 1.00 & 0.10 & -0.07 & $0.73^{*}$ & -0.10 \\
\hline G & & & 1.00 & -0.09 & 0.03 & $0.23^{*}$ \\
\hline M & & & & 1.00 & 0.09 & $-0.16^{*}$ \\
\hline R & & & & & 1.00 & -0.10 \\
\hline ND & & & & & & 1.00 \\
\hline
\end{tabular}

(Note: * denotes a statistically significant at $5 \%$ level.)

\subsubsection{Test results on the 1st Hypothesis}

The 1st hypothesis was postulated to find any financial components to characterize the leverage of the firms belonging to chaebols in the Korean capital market with applying the panel data (i.e., longitudinal data) model. Among the three regressands such as BVLEV1, BVLEV2, and MVLEV1, Both DVs such as BVLEV1 and MVLEV1 chose the pooled-OLS model as the best ones after implementing the panel data model. However, the model with the DV of BVLEV2 (as for the degree of financial leverage) was not explained at all across the pooled OLS, the fixed effect(FE), and the random
effect(RE) model under the selection criteria suggested by Park[19] for the panel data analysis. Therefore, the following table, Table 5, were the results of the regressions obtained for the book-value and market-value based debt ratios, respectively.

[Table 5] The Results From the Panel Data Analyses

(Model 5-1) For a book-value based leverage ratio (BVLEV1) as a DV:

$$
\begin{aligned}
& \text { BVLEV1it }=0.64-0.80 \text { PFTDit } \\
& \text { (t-statistic) } \quad(15.98) * \quad(-3.18)^{*} \\
& +(5.54 \mathrm{E}-16) \text { SIZEit }+0.21 \mathrm{GROWTHit} \\
& \text { (0.84) (1.40) } \\
& +0.01 \mathrm{MVBVit}-(5.86 \mathrm{E}-14) \mathrm{RISKit} \\
& (0.49) \quad(-2.47)^{*} \\
& \text { - 8.49NDTSit }-0.01 \mathrm{f} 2007+0.03 \mathrm{f} 2008 \\
& (-3.12)^{*} \quad(-0.49) \quad(0.65) \\
& +0.004 f 2009-0.007 f 2010-0.02 f 2011 \\
& (0.10) \quad(-0.18) \quad(-0.45)
\end{aligned}
$$

F-value* $=3.62, R^{2}=17.57 \%$, Adjusted $R^{2}=7.02 \%$

(Note: * indicates that the independent variable (IDV) is statistically significant at the $5 \%$ level.)

(Model 5-2) For a market-value based leverage ratio (MVLEV1) as a DV:

MVLEV1it $=0.77-0.94 \mathrm{PFTDit}$

(t-statistic) $\quad(18.05)^{*} \quad(-3.48)^{*}$

$+(1.52 \mathrm{E}-15)$ SIZEit +0.27 GROWTHit

$$
(2.15)^{*} \quad(2,71)
$$

- 0.12MVBVit - (9.35E-14)RISKit

$$
(-8.28)^{*} \quad(-3.69)^{*}
$$

- 6.60NDTSit $-0.04 \mathrm{f} 2007+0.04 \mathrm{f} 2008$

$$
(-2.27)^{*} \quad(-0.89) \quad(1.02)
$$

$+0.001 \mathrm{f} 2009-0.01 \mathrm{f} 2010-0.02 \mathrm{f} 2011$
$(0.03)$
$(-0.30)$
$(-0.54)$

F-value* $=17.54, R^{2}=50.78 \%$, Adjusted $R^{2}=47.89 \%$

(Note: * indicates that the independent variable (IDV) is statistically significant at the $5 \%$ level.) 


\subsubsection{Test results on the 2nd Hypothesis}

In the hypothesis, one of the present issues on the level of the chaebol firms was posited such as whether a firm classified into the chaebol possesses any discriminating components in regard to capital structure which may be different from those of the non- chaebol. Any plausible discriminating variables entered into the probit model were selected as PM, MVE, MVBV, RISK, GROWTH, NDTS, FOS, FCFF, and industry dummies such as from IND1 to IND5, as defined in [Table 2]. Before exercising the probit model, stepwise multiple regression models were separately run for each model with the DV of BVLEV1 and MVLEV1, respectively. Based upon the results available, it was meaningful to find that a firm belonging to the chaebol showed its higher book-value based leverage ratio than that of its counterpart, but did not show any statistical difference in market-valued leverage between the two groups. These findings may suggest an important implication that one of the traditional myths pervasive in the Korean capital market, tends to be no more prevalent and may decrease over time: <Myth $>$ A firm in the chaebol may maintain a higher debt ratio by exploiting its advantageous status towards the domestic government. Furthermore, the present findings were not consistent with those obtained in [3] and [5] which found higher levels of leverage maintained by the firms in the chaebols across the bookand market-value bases in the period of the early 1990s and that of the early 2000s. Subsequent to the conflicting results of the present study between BVLEV1 and MVLEV1 on the level of capital structure for the chaebol firms, it may be interesting to identify any possible elements discriminating between the two groups on the subject for further investigations or interpretations, as posited in the 2 nd hypothesis. The followings were the output, utilizing the probit model with employing the aforementioned control (or independent) variables.

[Table 6] Output of the Probit Analysis to Identify Any Statistically Significant Discriminators between a Firm belonging to the Chaebol and to the Non-chaebol on Capital Structure.

\begin{tabular}{|l|l|l|}
\hline IDV & Coefficient & Chi-square \\
\hline Intercept & -0.77 & $12.83^{*}$ \\
\hline PM & 2.83 & $4.59 *$ \\
\hline MVE & $4.15 \mathrm{E}-13$ & $26.17 *$ \\
\hline
\end{tabular}

\begin{tabular}{|l|l|l|}
\hline GROWTH & 0.92 & 1.12 \\
\hline RISK & $2.8 \mathrm{E}-12$ & $6.04^{*}$ \\
\hline MVBV & 0.006 & 0.004 \\
\hline NDTS & 31.46 & 2.88 \\
\hline FOS & -0.008 & 1.15 \\
\hline FCFF & $-346 \mathrm{E}-15$ & $4.31^{*}$ \\
\hline IND1 & -0.65 & $6.32^{*}$ \\
\hline IND2 & -5.97 & 0.001 \\
\hline IND3 & -0.19 & 0.50 \\
\hline IND4 & -0.34 & 1.49 \\
\hline IND5 & 0.17 & 0.41 \\
\hline Goodness of Fit & & $290.004^{*}$ \\
\hline
\end{tabular}

(Note 1)*: Significant at the $5 \%$ level with respect to the chi-square test

(Note 2) The coefficients were estimated by the method of maximum likelihood (ML). The test for overall goodness of fit was performed by the likelihood ratio(LR) test, while the Wald test was used to test for the significance of each individual coefficient.

\subsubsection{Test results on the 3rd Hypothesis}

As illustrated in the previous section, an enhanced version of a 'financial burden' applied from the 'Dupont' system was separately analyzed for each component in the context of TIE(times-interest-earned). It may be one of the practically referred leverage ratios in the Korean capital market, which may directly be related to measure a firm's bankruptcy risk, esp., after the Asian financial crisis. For mutual complement between the parametric (i.e., independent samples t-test) and the non-parametric statistics(i.e, Wilcoxon-Mann-Whitney test), two separate outcomes for each factor comprising the enhanced equation were presented in the following table.

[Table 7] Results on the parametric(t-stattstic) and nonparametric(z-statistic) for an enhanced version of the 'Financial Burden' between the firms belonging to the chaebols and their counterparts

\begin{tabular}{|c||c|c||c|c|}
\hline IDV & $\boldsymbol{t}$-statistic & $\boldsymbol{p}$-value & $\begin{array}{c}\boldsymbol{z} \text {-statis } \\
\text { tic }\end{array}$ & $\begin{array}{c}\boldsymbol{p} \text {-val } \\
\boldsymbol{u} \boldsymbol{e}\end{array}$ \\
\hline INTRATE & 2.06 & $0.040^{*}$ & -1.13 & 0.257 \\
\hline BDRELY & -5.65 & $<.001^{*}$ & 5.36 & $<.001^{*}$ \\
\hline BATURN & -1.24 & 0.214 & 0.039 & 0.969 \\
\hline MDRELY & -1.49 & 0.137 & 1.54 & 0.123 \\
\hline MATURN & -0.94 & 0.345 & 2.05 & $0.040^{*}$ \\
\hline SEBIT & -1.05 & 0.293 & 1.35 & 0.178 \\
\hline RTIE & -0.94 & 0.349 & 2.65 & $0.008^{*}$ \\
\hline
\end{tabular}

(Note 1$) *$ : statistically significant at the $5 \%$ level

(Note 2) INTRATE: Interest charges/Liabilities, BDRELY: Liabilities/Book-value of assets, BATURN: Book-value of Assets/Sales, MDRELY: Liabilities/ Market-value of assets, MATURN: Market-value of assets/Sales, SEBIT: Sales/EBIT, RTIE=Interest charges/EBIT 


\subsection{Interpretations}

On the results of the 1st hypothesis test, PFTD, as a proxy measuring profitability for the firms belonging to the chaebols, showed its negatively significant influence on both the book-value and the market-value leverage ratios as shown in the previous section. PFTD defined as EBITDA/total assets was used as a profitability indicator as in [9], which may have an relative advantage over other profitability measures such as EBIT/total assets and net income/equity(i.e., ROE), in that it may capture non-cash expenses to account for a firm's profit in cash. The findings of the present study with a pooled OLS analysis were consistent with those of the previous studies on the capital structures of the large size firms listed in the U.S. and Korean capital markets.[6] Subsequently, the negative relationship between the PFTD of the firms in the chaebols and the debt ratios across the BVLEV1 and MVLEV1, may suggest that Myers' pecking order theory for the financing of investments, may be pervasively applicable to the cases of the chaebol firms' capital structures in the domestic market. Moreover, in association with the outcome of the 2nd hypothesis indicating a higher level of profitability (PM) of the firms in the chaebols than their counterparts, this phenomenon of the negative relationship with the capital structure, seemed to be more distinct or significant to the chaebol firms than the non-chaebol counterparts. Second, the predictor, RISK, as a measure for a firm's volatility of earnings, also showed its negative and statistically significant relationship with the two types of a debt ratio. Even if many previous researches had employed the standard deviation of 'EBIT' during the sample period as a proxy for a firm's business risk [3],[20], this particular study instead, employed 'net income(NI)' (not 'EBIT') to calculate its standard deviation to measure for RISK. This was largely due to the assumption on a high degree of leverage (related to interest expenses) traditionally maintained by the Korean firms including those belonging to the chaebols. The negative relationship of RISK with leverage, seemed to imply that the sample firms were likely to implement their strategies of a target optimal capital structure, based upon the context of the traditional trade-off theory in finance. In other words, this finding evidenced that the leverage ratios of the firms belonging to the chaebols, seemed to be lowered down to the target leverage ratio, due to the risk factor which accounted for the present value(PV) of costs of financial distress, according to the underlying theory. Moreover, a non-debt tax shield(NDTS) presented by DeAngelo \& Masulis[21] assuming that the investment-related tax shields were economically significant relative to debt tax shields, was also tested to find its possible influence on the capital structure of a firm in the chaebol in the Korean capital market in this study. The proxy variable for NDTS in this study was defined as depreciation deductions such as depreciations \& amortizations scaled by total assets as in [8] and [22]. The expected sign of NDTS seemed to be conflicting and perverse in the finance literature, given that interest tax shields may be substituted by non-debt tax shields. To describe, Bradley et al.[23] found that the NDTS was in proportion to a firm's market value based leverage ratio with or without including industry classifications. While Boquist \& Moore[24] suggested that the function of this control variable at the firm level seemed to be positively or insignificantly related to capital structure, Bowen et al.[25] showed a negatively significant relationship between the NDTS and the average leverage ratio at the industry level. Kim \& Berger[6] also found that its effect on capital structure was statistically insignificant and minimal as well, for the large size firms including those in the chaebols in the early 1990s. Regarding the present finding on the negatively significant relationship across the differently measured leverage ratios, may suggest unexplored implications on this issue, with a directional expectation, $(-)$, of the function of NDTS on capital structure. In other words, Korean firms currently tend to take advantage of the tax reduction resulting from the NDTS with synthesizing their lower debt levels to decrease bankruptcy risks, as the domestic capital market is now in transition to be classified into advanced capital markets with its longer history and mature status, in comparison with those in the early 1990s.

Moreover, a predictor, SIZE, for a firm's size, showed a positively significant effect on the market-value based debt ratio, as shown in the previous section. In this paper, SIZE was proxied by the sales amount of a firm belonging the chaebols at fiscal year-end, while the majority of studies employed a firm's assets as a size 
variable with or without a logarithm transformation. One of the rationale that the sales amount or a firm size, may be a better proxy for SIZE, may result from the fact that most large firms in the Korean capital market seemed to actively expand their market shares measured in the sales amount, (rarely in the total assets), since the amount was directly related to their profits in terms of EBIT or NI. Its positive relationship with capital structure may be in conformity with the findings of Kim[1], suggesting the traditional finance theory that a large size firm may maintain a higher debt ratio than a small size firm has, due to the lower extent of total risk by diversification and the higher probability engaging in the mature industries with stable cash flows. Du \& Dai[22] also presented that a firm with large size may maintain higher leverage than its counterpart as a small size one arising form the inverse relationship between the size and the unobservable credit risk. Regarding the MV/BV ratio as a control variable, Fama \& French[26] described that a positive relation between market value/book value (as $\mathrm{P} / \mathrm{B}$ ) and share issues is expected by many models, regardless of the rational pricing assumptions. The negative and significant effect of $\mathrm{MV} / \mathrm{BV}$ on debt ratio in this study seemed to be consistent with their view, in that issuing more equity mostly commensurated with the lower market-value based debt ratio. In addition, the study performed by Hovakimian et al.[27] also provided evidence that the coefficient estimates for market-to-book ratio were negatively significant on leverage in the tested models, indicating that firms with high $\mathrm{MV} / \mathrm{BV}$ seemed to choose less leveraged forms of financing.

Among the explanatory variables engaged as possible discriminating effects between the firms belonging to the chaebols and the non-chaebols in the 2nd hypothesis, it may be one of the particularly intriguing findings such as the significantly negative coefficient of the variable, FCFF, which indicated that the larger was the FCFF(i.e., free cash-flow to the firm) of a firm, the lower was the probability that a firm was classified as a member firm in the chaebol. It was surprising to find this outcome in the domestic market since it was generally believed that Korean chaebols were likely to maintain the levels of their cash flows on a more conservative basis than their counterparts, not belonging to the chaebols, in order to prevent any further shortage of liquidity since the Asian financial crisis in the late 1990s. In line with the present empirical finding, this belief may be regarded as a myth, not a reality, in the contemporary Korean capital market, presuming possible heavier capital expenditures by the chaebol firms, which was measured in terms of the accounting definition of [net changes of the amount of assets during a fiscal year] shown in [Table 2]. Moreover, the coefficient on the measure of 'cash flow to sales' ratio was negatively significant on leverage at the $5 \%$ level as tested in Low \& Chen[28] and they analyzed this phenomenon as internally-generated funds available allowed firms to depend less on debt financing congruent with the Myers' pecking order theory. Coupled with their analysis, the relatively lower level of FCFF reserved by the chaebol firms in the present study, may result in the statistically significant difference between the two compared groups, relative to the book-value based capital structure as presented earlier.

Finally, the findings from the 3rd hypothesis test showed the following conclusion on the enhanced version of the 'Dupont' system applied to the TIE(times-interestearned), which was presented in [Table 7]. Statistically, RTIE as interest charges/EBIT, showed its evidence that the two groups (i.e., chaebols vs. non-cheabols) had different probability distributions in the context of nonparamentic statistics, while the means of these groups under normal distributions were not different in a parametric statistics. (e.g., the mean of the chaebols was 0.8670 ; that of the non-chaebols was 0.3432) Furthermore, it may be worth noting that BDRELY denoting the ratio of liabilities at book to total assets at book-value, provided evidence that the firms belonging to the chaebols may maintain their debt burden, statistically larger that their counterpart, regardless of the assumption on the shape of distributions. (e.g., the mean of the chaebols was 0.5671 ; that of the non-chaebols was 0.4635) As a conclusion, among all the proposed variables such as INTRATE, BDRELY, MDRELY, BATURN, MATURN, and SEBIT in the equation of the 3rd hypothesis test, only BDRELY showed its statistically significant influence to discriminate between the chaebol firms and their counterparts with the larger mean of the chaebol ones, whose result was consistent and supported by the higher average debt ratio of the group (at book-value) shown in the 2 nd hypothesis test. 


\section{Concluding Remarks}

This study investigated a prolonged, contentious subject pervasive in the Korean capital market, which was related to financial attributes of the firms belonging to the chaebol. As the diversity of its investor classifications such an overseas institutional or hedge-fund investors, is broadly expanded, given the transition of the domestic market towards the advanced financial market, it may be of particular importance to identify any robust or consistent financial profile across time periods, relative to capital structure for the firms in the chaebol.

Three hypotheses were postulated and tested for each corresponding issue commensurated with the theory of capital structure. The followings were primary findings and their implications derived from the present research. First, the regressors denoted by PFTD, RISK, NDTS, showed their evidence to have statistically significant relationships with all the differently measured debt ratios (i.e., across the book- and market-value leverage), in addition to the two other significant IDVs such as SIZE and MVBE affecting the levels of the market-valued capital structures for the firms belonging to the chaebol. Of particular, PFTD, as a proxy for profitability for the chaebol firms showed its negative and statistically significant influence on leverage, which may suggest an interesting implication that the Myers' pecking order theory may be still, pervasively applicable to the cases of the chaebol firms in the domestic market. Another significant explanatory variable, NDTS, which seemed to have rarely been employed to test for leverage for the firms in the emerging capital markets, was found to have a negative effect on the level of leverage, as previously explained. In the 2nd hypothesis test, the evidence showed that the larger was the FCFF of a firm, the lower was the probability that a firm may be classified as a member firm in the chaebol, while BDRELY defined as the ratio of liabilities to total assets (at the book-value basis), among all the proposed components comprising the enhanced 'Dupont' system, only showed its statistically significant effect on leverage to discriminate between the firms in the chaebols and their counterparts, in the context of the parametric and nonparametric tests.

Even if the present study bears assumed weaknesses as an empirical research such as employing different sampling criteria and distinct methodologies employed, it may shed new light on the contemporary financial profile of the firms in the Korean chaebols, which may contribute to the following respects. First, this study may examine the results from the year of 2006 to 2011 as to whether the leverage ratios of the firms in the chaebol have been, on average, restructured by the debt policies regularly implemented by the domestic government to a large extent. Second, any financial components to discriminate between the chaebol firms and their counterparts were compared with those in the previous literature as in [5] and [6] for checking any robustness and consitency, which may be useful to enhance the current status of the Korean capital markets progressing into the advanced one.

\section{References}

[1] Hanjoon Kim, "Financial Profile of Capital Structures for the Firms Listed in the KOSPI Market in South Korea", Unpublished working paper, 2013.

[2] Franco Modigliani, Merton H. Miller, "The Cost of Capital, Corporation Finance, and the Theory of Investment", American Economic Review, Vol.48, No.3, pp. 261-297, 1958.

[3] Hanjoon Kim and Paul D. Berger, "The Management Characteristics of Korean Chaebols vs. non-Chaebols: Differences in Leverage and Its Ramifications: Myth or Reality?" Advances In Management, Vol.2, No.2, pp. 26-35. 2009

[4] Dongsung Cho, Hankuk Chaebol Yeongu, Mail Kyoungje Shimmun Sa, Seoul, Korea, 1991.

[5] Hanjoon Kim, "Financial Leverage of Korean Business Conglomerates "Chaebols" in the Post-Asian Financial Crisis", The Korea Academia-Industrial cooperation Society, Vol.12, No.2, pp. 4359-4368, 2011.

DOI: http://dx.doi.org/10.5762/KAIS.2011.12.2.699

[6] Hanjoon Kim and Paul D. Berger, "A Comparison of Capital Structure Determinants: The United States and The Republic of Korea," Multinational Business Review, Vol.16, No.1, pp. 70-100, 2008. DOI: http://dx.doi.org/10.1108/1525383X200800004

[7] Krishnan, V. Sivarama, R. Charles Moyer, "Performance, Capital Structure and Home Country: An Analysis of 
Asian Corporation", Global Finance Journal, Vol 8, No.1, pp.129-143, 1997.

DOI: http://dx.doi.org/10.1016/S1044-0283(97)90010-7

[8] Rataporn Deesomsak, Krishna Paudyal, and Gioia Pescetto, "The Determinants of Capital Structure: Evidence from the Asia Pacific region", Journal of Multinational Financial Management, Vol.14, pp. 387-405, 2004.

DOI: http://dx.doi.org/10.1016/j.mulfin.2004.03.001

[9] Bassam Fattouh, Pasquale Scaramozzino, Laurence Harris, "Capital Structure in South Korea: a Quantile Regression Approach", Journal of Development Economics, Vol.76, pp. 231-250, 2005.

DOI: http://dx.doi.org/10.1016/j.jdeveco.2003.12.014

[10] Dea-Keun Park, Jeongsun Yun, Bong-Hwan Cho, "A Research on the Determinants of Investment of Chaebol Firms", The Korean Journal of Financial Management, Vol.26, pp.35-61, 2009.

[11] Jeong Pyo Choi, "A Comparison of Management Structure between the Rising and Falling Chaebols", The Korean Journal of Industrial Organization, Vol.18, pp. 79-100, 2010.

[12] Edward B. Deakin, "Distribution of Financial Accounting Ratios: Some Empirical Evidence", The Accounting Review, Vol.51, pp. 90-96, 1976.

[13] Mo A. Mahmood, Edward C. Lawrence, "A Performance Analysis of Parametric and Nonparametric Discriminant Approaches to Business Decision Making", Decision Sciences, Vol.18, pp. 308-326, 1987.

DOI: http://dx.doi.org/10.1111/j.1540-5915.1987.tb01524.x

[14] Cheol-Jung Kim, Enterprise Value Based Business Analysis (3rd ed.), Myoungkyung-Sa, Seoul, 2010.

[15] Jeffrey M. Wooldridge, Introductory Econometrics: A Modern Approach (4th ed.), South-Western Cengage Learning, 2009.

[16] Ramu Ramanathan, Introductory Econometrics with Applications(2nd ed.), Dryden, 1992.

[17] Hanjoon Kim, "A Review on the Financial Profile of Profitability for the KOSDAQ Listed Firms Headquartered in 'Chungcheong' Province in the Republic of Korea", Unpublished working paper, 2013.

[18] Hanjoon Kim, "Determinants of Leverage for Manufacturing Firms Listed in the KOSDAQ Stock Market", The Korea Academia-Industrial Cooperation Society, Vol.13, No.5, pp. 2096-2109, 2012.

DOI: http://dx.doi.org/10.5762/KAIS.2012.13.5.2096

[19] Hun Myoung Park, Practical Guides To Panel Data Analysis, 2011. Available From: http://www.iuj.ac.jp/faculty
(Accessed on Aug. 15, 2013)

[20] Sheridan Titman, Reberto Wessels, "The Determinants of Capital Structure Choice", Journal of Finance, Vol.43, No.1, pp. 1-9, 1988.

DOI: http://dx.doi.org/10.1111/j.1540-6261.1988.tb02585.x

[21] H. DeAngelo, R. Masulis, "Optimal Capital Structure under Corporate and Personal Taxation", Journal of Financial Economics, Vol.8, pp.3-30, 1980.

DOI: http://dx.doi.org/10.1016/0304-405X(80)90019-7

[22] J.Du, Y. Dai, "Ultimate Corporate Ownership Structures and Capital Structures: evidence from East Asian economies", Corporate Governance: An International Review, Vol.13, No.1, pp.60-71, 2005.

DOI: http://dx.doi.org/10.1111/j.1467-8683.2005.00403.x

[23] Michael Bradley, Gregg A. Jarrell, E. Han Kim, “On the Existence of an Optimal Capital Structure: Theory and Evidence", Journal of Finance, Vol.39, No.3, pp. 857-878, 1984.

DOI: http://dx.doi.org/10.1111/j.1540-6261.1984.tb03680.x

[24] John A. Boquist, William T. Moore. "Inter-industry Leverage Differences and the DeAngelo-Masulis Tax Shield Hypothesis", Financial Management, pp. 5-9, 1984.

DOI: http://dx.doi.org/10.2307/3665118

[25] Robert M. Bowen, Lane A. Daley, Huber Jr., C. Charles, "Evidence on the Existence and Determinants on Inter-industry Differences in Leverage", Financial Management, Vol.11, pp. 10-20, 1982.

DOI: http://dx.doi.org/10.2307/3665227

[26] E. Fama, K. French, "Capital Structure Choices", Critical Finance Review, Vol.1, pp.59-101, 2012.

DOI: http://dx.doi.org/10.1561/104.00000002

[27] A. Hovakimian, G. Hovakimian, H. Tchranian. "Determinants of Target Capital Structure: The Case of Dual Debt and Equity issues", Journal of Financial Economics, Vol.71, 517-540, 2004.

DOI: http://dx.doi.org/10.1016/S0304-405X(03)00181-8

[28] P. Low, C. Kung, "Diversification and Capital Structure: Some International Evidence", Review of Quantitative Finance and Accounting, Vol. 23, pp. 55-71, 2004.

DOI: http://dx.doi.org/10.1023/B:REQU.0000037064.15144.04 
Hanjoon Kim

[Regular member]

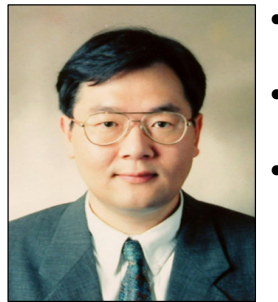

- Sept. 1987 : The George Washington Univ., MBA

- Jan. 1999 : Boston University DBA (Major: Finance)

- Mar. $2010 \sim$ Present : Hoseo Univ. Dept. of Business Administration, Assistant Professor

$<$ Research Interests $>$

Corporate Finance, International Finance, Mergers \& Acquisitions, Equity Valuation 